\title{
DESIGN OF PANCASILA IN TROIKA TRAINS
}

\author{
Ipik Permana \\ Universitas Swadaya Gunung Jati \\ ipermana44@gmail.com, \\ Hamirul \\ STIA Setih Setio \\ hrul@ymail.com
}

\begin{abstract}
Various kinds of cases that occur in this country are caused by the lack of practice of Pancasila which is the basis of this country, ranging from various kinds of problems that occur nowadays to widespread corruption cases and many more cases involving politicians, businessmen and bureaucrats in this article called the troika train has three horses that can draw a train which is analogous as a country, this term is taken from Russia for a small train drawn by three horses and this is analogous to the three roles of politicians, businessmen and bureaucrats as government representatives. Politicians, bureaucrats and entrepreneurs where they do more actions that are not in accordance with the Pancasila and harm the community and cause the gap of poverty to deepen between one another. In each component of precepts that exist in pencasila should be applied to all the actions of politicians, businessmen and bureaucrats in terms of serving the community and if all the precepts have been fixed, of course the thing called corruption will not happen in this country and of course this corrupt act is detrimental and many people really hope that the troika train (Politicians, Bureaucrats and Entrepreneurs) can implement and apply the spirit of Pancasila in every policy for politicians and services for all bureaucrats and entrepreneurs and run their businesses in accordance with the essence of Pancasila.
\end{abstract}

Keywords: Pancasila, Train Troika, Entrepreneurs, bureaucrats, politicians.

\section{INTRODUCTION}

Various kinds of cases that occur in this country are caused by the lack of practice of Pancasila which is the basis of this country, ranging from various kinds of problems that occur today to widespread corruption cases and many more cases involving politicians, businessmen and bureaucrats in this case the government and in the article this is called a troika train that has three horses that can pull a train, this term is taken from Russia for a small train drawn by three horses and this is analogous to the three roles of politicians, businessmen and bureaucrats as government representatives.

Politicians, if we talk about the role of politicians in this country, is very central and this is a position that is very much in demand in the election battle that usually represents an area, both regency / city and province and even to the national realm which becomes the representative of the people and moves as legislative Laws that are sometimes misused for personal or group interests and how important the position of politicians in this country are so that they can sometimes change regulations for this country and sometimes they produce articles or laws that are barren because the process of making it is not with the Down to Top model, but more many go to the Top to Down and sometimes there are articles or laws that are ordered and even a lot of people are involved in various corruption cases from the small ones up to the very big cases at the moment namely E-KTP. 
When linked to political parties as a vehicle for politicians involved in corruption cases from various PDIP sources with 157 cases (10.7), GOLKAR with 118 cases (7.5), PAN with 41 cases (6.6), PKB 34 Cases $(6,6)$, PKPI 5 cases (5.3), UN 9 cases (4.4), Gerindra 20 cases (4.3), PPP 21 cases (8.8), Hanura 13 Cases (3.3), Democrats 47 cases (2.7) and PKS 4 cases (0.4).

Quoted from the article released by the English media, The Daily Mail Thursday (01/28/2016), Indonesia is listed as the most corrupt and cleanest country called the Corruption Perception Index, showing an increase in position and points from the previous year. This year, where Indonesia was first under Jokowi's control, Indonesia got 34 points and was in position 88. Corruption that occurred in the realm of politicians also occurred to bureaucrats from various cases ranging from bribery, procurement of goods and services, misuse of the budget, Licensing, Levies, TPPU, hinder the KPK process. Of the several cases above, of course, it is closely related to politicians who play a role in the process of legalizing or abandoning a project, so that politicians and bureaucrats are closely related to corruption cases that occur because of the interrelationship between one another.

Entrepreneurs are business people who do business or projects that require government support starting from place permits and so on and from this process linkages with bureaucrats in obtaining licenses in every business move they run and this is an opportunity for bureaucrats to get quota if you want a permit and so on related to the smooth running of the business, of course by paying more so that the desired permit can be granted and this is certainly also related to politicians in the regulations made to smooth entrepreneurs in implementing the program they want by involving bureaucrats. inside it.

There are so many discourses that invoke the Pancasila on these various occasions given to the community and students, etc., but this has not been felt effective if this is not done also by politicians, bureaucrats and businessmen whose actions are not in accordance with the Pancasila and harming the community and causing poverty to deepen between one another.

\section{THEORETICAL BASIS}

To better understand the Pancasila contained in the 1945 Constitution, it is better to understand the principles contained in the Pancasila according to (Soeprapto: 1995). The principles are as follows:

a. We acknowledge that all life in this world is everything determined by a provision outside the human self which the Indonesian people call God Almighty. It is the creator, regulator, and determinant of everything. Even so before an incident overflows us, humans must try their best. As a further consequence, humans must be grateful and report anything that is abundant. We believe and are devoted to God Almighty, this is the principle of faith and devotion to God the One.

b. As a further consequence, we put everything in this world in accordance with its nature, dignity and dignity. Nature is the whole original nature, provision or 
disposition that is attached to the existence of something. Nature is innate as the creation of God Almighty. Harkat is the ilia contained in that nature. Each creature created by God the Almighty has its own dignity in accordance with its nature. Dignity is an honorable position in accordance with the dignity.

c. In order to carry out a common life, the Indonesian people long for unity, the union between individuals and society, leaders and those who are led, creatures with their God. This unity of understanding is centered on the only nation in the unitary state of the Republic of Indonesia. The state does not take sides with the strongest group, nor does it side with the group which is considered the most important. The state guarantees the safety of the life of the nation as whole as unity. This is the principle of unity.

d. The Indonesian people have a principle, that in finding or determining decisions that will bind all citizens is carried out by deliberation to reach consensus. Differences of opinion are acknowledged and respected, but not exaggerated or exaggerated, endeavored to be approached, to be a mutual agreement. Self-control becomes the main key for deliberation to reach consensus. This is the principle of deliberation to reach consensus. This is the principle of society for consensus.

e. The welfare of all people is the goal of living together. All efforts are aimed at the realization of this principle, social justice.

Indonesia's development vision in RPJP 2005-2025 is an independent, fair and prosperous Indonesia (Roziq, 2016):

1. Able to realize equal and equal life with other countries to rely on their own abilities and strengths.

2. quality of human resources, level of welfare, and stability of the system and political and legal institutions.

3. Fair, means that there are no ups and downs of discrimination in any form, both between individuals, gender and region.

4. Prosperity, meaning measured by the level of compliance with all with all the necessities of life.

Roziq (2016), states that the integration of Pancasila values in culture-based character education and school community must be characterized by:

1. Pancasila values become a national character-based value source for the education of the cultural environment of schools, families, local community environments that are developed in accordance with national culture by paying attention to local knowledge so that it is easily understood, internalized and practiced.

2. Character education must be developed through a design-based culture and school community and integrated with the ability of citizens for the cognitive, affective, psychomotor, and social domains.

3. Education will not be effective and efficient if education is implemented narrowly to leave elements of civilization and empowerment in the context of national education. In this case between education and acculturation and empowerment is 
unity and character education is determined by three things: knowing, moral moral feelings, and moral behavior.

4. The culture of the environment and the school community, the family is the most effective media in character education for the nation's education.

5. Programs and extra curricular activities must be integrated with the Pancasila value in education and the school community based on national culture.

6. Embedding the basic concepts of Pancasila into pillars of nationality: Pancasila, the 1945 Constitution in the Unitary State of the Republic of Indonesia (NKRI), and Single Bhineka Every type, path, and education both in formal, informal and non-formal.

7. Repositioning Pancasila education and citizenship education, and national identity as a political contract for an independent, progressive, just and prosperous Indonesian nation.

8. Implementing national character education implied in citizenship education is a joint responsibility, not just the duty of subjects or Civics courses but must be a shared responsibility of all subjects of national education.

9. The approach developed is a multidisciplinary and multi-dimensional approach that is holistic so that it can be developed into a nation that has a strong mental attitude.

\section{RESEARCH METHODS}

The approach in this study is normative Descriptive by using secondary data and specifications in this study is a descriptive analysis. The technique for analyzing the data in this study is the qualitative analysis method, which is data assessment in the form of numbers instead of data in the form of numbers.

\section{DISCUSSION}

The Regional Representative Council consists of provincial representatives, DPRD and DPRD who are representatives of the people who should represent the aspirations of the community which, when viewed from the moral values and norms carried out, should be able to express the Pancasila values in the actions and Pancasila as well as a source of material law and elaboration. Pancasila values, where:

a. Pancasila as Grundnorm (basic norms), for the life of the nation, society and the state of Indonesia. If the Pancasila is the basis for making a law, it must always use the norms found in each of the precepts contained in the Pancasila and all the acts carried out by the representatives of the people always consider each principle in the Pancasila and all of them will surely include elements of all precepts in the Pancasila so that there will be no fraud in the making of regulations or the Law which is made only beneficial for some groups and with the Pancasila value adopted by the members of the House as representation of the representatives of the people can be carried out properly. 
Bureaucrats who carry out a regulation in this country should also carry out the noble values of the Pancasila from the first principle to the fifth principle in the process of carrying out daily activities in serving the community so that in the process the service will depend heavily on serving instead of being served.

b. Pancasila is not only the basic norms of legal life and orderly Indonesian law, but also the basic norms of other norms such as moral norms, morality and ethics and so on. If the application of Pancasila as a basic norm can be reflected by troika horses (politicians, bureaucrats and entrepreneurs) can run all their jobs and responsibilities in accordance with the basic norms that exist, then the incidence of corruption, collusion and Nepotism in Indonesia will decrease significantly.

c. Pancasila requires that Indonesian law order is also in harmony with moral norms, morality. With the Pancasila all activities of troika horses (politicians, bureaucrats and entrepreneurs) can create a synergy that runs towards the positive so that service in making laws or regulations and bureaucrats in serving the community in accordance with existing norms and entrepreneurs also do their business accordingly with regulations in accordance with the laws in our country that adhere to the Pancasila.

In each component of precepts that exist in the pencasila should be applied to all the actions of politicians, businessmen and bureaucrats in terms of serving the community and if all precepts have been fixed, the thing called corruption will not happen in this country and of course this act of corruption is detrimental to many who really hope that the troika train (Politicians, Bureaucrats and Entrepreneurs) can carry out and apply the spirit of Pancasila in every policy for politicians and services for all bureaucrats and entrepreneurs and run their businesses in accordance with the essence of Pancasila.

\section{CONCLUSION}

Politicians, bureaucrats and entrepreneurs where they do more actions that are not in accordance with the Pancasila and harm the community and cause the gap of poverty to deepen between one another.

In each component of precepts that exist in pencasila should be applied to all the actions of politicians, businessmen and bureaucrats in terms of serving the community and if all the precepts have been fixed, of course the thing called corruption will not happen in this country and of course this corrupt act is detrimental and many people really hope that troika trains (Politicians, Bureaucrats and Entrepreneurs) can implement and apply the spirit of Pancasila in every policy for politicians and services for all bureaucrats and entrepreneurs and run their businesses in accordance with the essence of Pancasila. 


\section{Reference}

Hamirul, Mempancasilakan Kereta Troika, Suara Bute Sarko, Media Online, 21 November 2017, https://news.suarabutesarko.com/artikel/1415mempancasilakan-kereta-troika

Herawati, R. (2015). Implikasi Sistem Pengisian Keanggotaan Dewan Perwakilan Daerah Republik Indonesia Terhadap Nilai-Nilai Pancasila. $M M H, 393-404$.

1Roziq, A. (2016). Integrasi Nilai-Nilai Pancasila Dalam Pendidikan Karakter Dan Budaya Bangsa Yang Berbasis Pada Lingkungan Sekolah. Rontal Keilmuan PPKn, 1-11.

Soeprapto. (1995). P-4 Sebagai Aktualisasi Nilai-nilai Pancasila dalam Hidup Berbangsa dan Bernegara. Jurnal Filsafat Agustus, 11-22.

Soeprapto, S. (1995). Aktualisasi Nilai-Nilai Filsafat Pancasila Notonagoro. Filsafat Agustus, 30-37. 